\title{
Candida xylanilytica sp. nov., a xylan-degrading yeast species isolated from Thailand
}

\author{
Chanita Boonmak, ${ }^{1}$ Savitree Limtong, ${ }^{2}$ Sasitorn Jindamorakot, ${ }^{3}$ \\ Somjit Am-In, ${ }^{3}$ Wichien Yongmanitchai, ${ }^{2}$ Ken-ichiro Suzuki, ${ }^{1}$ \\ Takashi Nakase ${ }^{1,3}$ and Hiroko Kawasaki ${ }^{1}$ \\ ${ }^{1}$ NITE Biological Resource Center, Department of Biotechnology (NBRC), National Institute of \\ Technology and Evaluation (NITE), Chiba, Japan \\ ${ }^{2}$ Department of Microbiology, Faculty of Science, Kasetsart University, Bangkok, Thailand \\ ${ }^{3}$ Central Research Unit, National Center for Genetic Engineering and Biotechnology, National \\ Science and Technology Development Agency, Pathumthani, Thailand
}

Correspondence

Hiroko Kawasaki

kawasaki-hiroko@nite.go.jp

\begin{abstract}
Xylan is a major component of hemicellulose, which constitutes about $40 \%$ of plant biomass. Hydrolysis of xylan into simple sugars is one of the important steps in the conversion of lignocellulosic material to value-added products. During an investigation of cellulose- and xylandegrading yeasts, two yeast strains that were able to use cellulose and xylan as sole carbon source were found to represent a phylogenetically distinct species in the Spathaspora clade. The closest species in terms of pairwise sequence similarity in the D1/D2 domain of the LSU rRNA gene was Candida subhashii. The novel species can be distinguished from the other species in the Spathaspora clade based on the ability to assimilate methanol and raffinose, growth in medium containing $60 \%$ glucose, and growth at $42{ }^{\circ} \mathrm{C}$. It ferments glucose but not other carbohydrates. The name Candida xylanilytica sp. nov. is proposed for this species. The type strain is $\mathrm{KU}-\mathrm{Xn} 11^{\top}$ $\left(=\right.$ NBRC $106499^{\top}=$ BCC $34694^{\top}=$ CBS $\left.11761^{\top}\right)$.
\end{abstract}

Xylan is the second most abundant polysaccharide in nature and is one of the principal components of hemicellulose in plant cell walls. Most xylans occur as heteropolysaccharides containing $\beta$-xylopyranose residues as the backbone with substituent acetyl, arabinofuranose and glucuronysyl residues in the side chains. In plants, hemicelluloses link between lignin and cellulose microfibrils. The xylan layer, which forms a covalent linkage with lignin and a non-covalent linkage with cellulose, is considered to be an important key to maintain cellulose integrity and protect the fibrils from degradation by cellulases (Beg et al., 2001; Gilbert et al., 2008). Therefore, hydrolysis of xylan into simple sugars is also one of the important steps to utilize and convert lignocellulosic materials to value-added products such as ethanol and biodiesel. Several yeasts, such as Candida ergatensis, Cryptococcus albidus, Pichia stipitis, Trichosporon cutaneum and a yeast-like fungus, Aureobasidium pullulans, have been reported to have xylan-utilizing ability (Beg et al., 2001; Bhadra et al., 2008).

The Spathaspora clade was recognized by Nguyen et al. (2006) and comprised Spathaspora arborariae, Spathaspora passalidarum and five anamorphic species in the genus

The GenBank/EMBL/DDBJ accession number for the D1/D2 domain sequence of the LSU rRNA gene of strain $\mathrm{KU}-\mathrm{Xn} 11^{\top}$ is $\mathrm{AB} 523752$.
Candida. The xylose-fermenting species, Candida lyxosophila and $S$. arborariae, were isolated from surface woodland soil in South Africa and rotting wood in Brazil, respectively, while Candida jeffriesii and S. passalidarum were found to associate with the gut of wood-boring beetles, Phrenapates bennettii in Panama and Odontotaenius disjunctus in Louisiana, USA (Cadete et al., 2009; Nguyen et al., 2006; van der Walt et al., 1987). The other three species of the Spathaspora clade do not ferment xylose. Candida insectamans and Candida materiae were found in frass of buprestid beetle larvae and rotting wood, respectively, while Candida subhashii was isolated from a fungal peritonitis patient in 2006 (Adam et al., 2009; Barbosa et al., 2009; van der Walt et al., 1972).

In the course of an investigation of cellulose- and xylandegrading yeast in Thailand, two yeast strains which were able to use cellulose and xylan as sole carbon source were found to represent a novel species in the Spathaspora clade, based on analysis of the D1/D2 domains of the largesubunit (LSU) rRNA gene sequence. In the present study, a novel species in the genus Candida is described.

Strains KU-Xn11 and KU-Xn20 were isolated from decayed corn cobs and decayed grasses, respectively, at the National Corn and Sorghum Research Center, Nakhon Ratchasima, Thailand, by an enrichment technique using 
xylan broth ( $1 \%$ oat spelt xylan, $0.67 \%$ yeast nitrogen base). The cultures were incubated on a rotary shaker at 150 r.p.m. at $25{ }^{\circ} \mathrm{C}$ for 5 days. The culture broth was spread on xylan agar ( $1 \%$ oat spelt xylan, $0.67 \%$ yeast nitrogen base, $2 \%$ agar) and incubated at $25{ }^{\circ} \mathrm{C}$ until yeast colonies developed. The different morphotypic colonies were purified by streaking on yeast extract/malt extract (YM) agar. Xylan and cellulose degradation was determined on xylan YM agar ( $1 \%$ oat spelt xylan, $0.3 \%$ yeast extract, $0.3 \%$ malt extract, $0.5 \%$ peptone, $2 \%$ agar) and carboxymethyl cellulose YM agar (1\% carboxymethyl cellulose, $0.3 \%$ yeast extract, $0.3 \%$ malt extract, $0.5 \%$ peptone, $2 \%$ agar). After incubation at $25{ }^{\circ} \mathrm{C}$ for 5 days, the culture plates were stained with $0.5 \%(\mathrm{w} / \mathrm{v})$ Congo red for $10 \mathrm{~min}$ and destained with $1 \mathrm{~N} \mathrm{NaCl}$ (Zhang et al., 2006). Strains KU-Xn11 and KU-Xn20 showed positive hydrolysis zones in xylan and cellulose degradation tests.

The strains were characterized morphologically, biochemically and physiologically according to the standard methods described by Yarrow (1998). Cultures grown on $5 \%$ malt extract agar, cornmeal agar, Fowell's acetate agar, diluted vegetable juice agar (Kagome Co., Japan) and YM agar were examined for ascospore formation. Individual strains and mixed cultures were incubated at $15{ }^{\circ} \mathrm{C}$ and $25{ }^{\circ} \mathrm{C}$ for up to 1 month. Fermentation of D-xylose was determined in Durham tubes containing $2 \%(\mathrm{w} / \mathrm{v})$ xylose and $0.67 \%$ yeast nitrogen base solution. After incubation at $25{ }^{\circ} \mathrm{C}$ for up to 28 days, the results were scored according to standard methods of fermentation of carbohydrates described by Yarrow (1998). Ubiquinones were extracted from intact cells cultivated in YM broth on a rotary shaker at $25^{\circ} \mathrm{C}$ for 3 days. Isolation, purification and identification of ubiquinone homologues were performed according to the method described by Mikata \& Yamada (1999). Genomic DNA was prepared according to Holm et al. (1986), as modified by Kaneko \& Banno (1991). The DNA base composition was determined by HPLC as described by Tamaoka \& Komagata (1984) using the DNA-GC kit (Yamasa Shoyu Co., Japan).

Sequences of the D1/D2 domain of the LSU rRNA gene were determined as described by Limtong et al. (2008). The sequences were compared pairwise by BLASTN search (Altschul et al., 1997) and were aligned with sequences of related species retrieved from GenBank using the multiple alignment program CLUSTAL x version 1.83 (Thompson et al., 1997). Phylogenetic trees were reconstructed from the evolutionary distance data with Kimura's two-parameter correction (Kimura, 1980) using the neighbourjoining method (Saitou \& Nei, 1987) and by the maximum-parsimony method using the max-mini branch-and-bound algorithm of MEGA version 4 (Nei \& Kumar, 2000; Tamura et al., 2007). Confidences for the phylogenetic tree were estimated from bootstrap analysis (1000 replicates) (Felsenstein, 1985).

The D1/D2 domains of the LSU rRNA gene of strains KU$\mathrm{Xn} 11$ and KU-Xn20 have identical sequences which are present as two distinct copies in the genome. One copy has seven consecutive T nucleotides (copy 1, $569 \mathrm{nt}$ ), the other has eight T nucleotides (copy 2, $570 \mathrm{nt}$ ) in the same region. This may result from variability in tandem repeats of the rRNA gene. The closest species in terms of pairwise sequence similarity was Candida subhashii, with $5.6 \%$ nucleotide substitution (32 bp) and 17 indels in copy 1 , and $5.8 \%$ nucleotide substitution (33 bp) and 16 indels in copy 2 . The two strains showed greater than $1 \%$ nucleotide substitution in the D1/D2 domain of the LSU rRNA gene and were presumed to represent a distinct species from Candida subhashii, according to the guidelines of Kurtzman \& Robnett (1998). Phylogenetic analysis based on the D1/D2 domain of the LSU rRNA gene demonstrated that the two strains formed a cluster with Candida insectamans with high bootstrap support and were related to the other known species of the Spathaspora clade (Fig. 1).

The two strains proliferated by multilateral budding and pseudohyphae were abundant (Fig. 2). The strains were negative for Diazonium blue $\mathrm{B}$ and urease reactions and had Q-9 as the major ubiquinone. Lipid accumulated in cells grown in $5 \%$ malt extract agar, cornmeal agar or YM agar after 5 days at $25{ }^{\circ} \mathrm{C}$. Ascospores were not produced from individual strains or mixed culture on $5 \%$ malt extract agar, cornmeal agar, Fowell's acetate agar, diluted vegetable juice agar or YM agar after 5 weeks at $15{ }^{\circ} \mathrm{C}$. Xylose fermentation was absent, similar to Candida insectamans, Candida materiae and Candida subhashii. The novel strains could be distinguished from the other species of the Spathaspora clade based on the ability to assimilate methanol and raffinose, growth in medium containing $60 \%$ glucose and growth at $42{ }^{\circ} \mathrm{C}$. Based on the data above, we concluded that the two strains represent a single novel species of the genus Candida in the Spathaspora clade, for which the name Candida xylanilytica sp. nov. is proposed.

\section{Latin diagnosis of Candida xylanilytica Boonmak, Limtong, Jindamorakot, Am-In, Yongmanitchai, Suzuki, Nakase et Kawasaki sp. nov.}

In liquido 'YM', post dies 3 ad $25{ }^{\circ} \mathrm{C}$, cellulae spheroideae, ovoidae, ellipsoideae vel elongatae, 3.2-9.5 $\times 3.2-23.2 \mu \mathrm{m}$, singulae, binae vel conglobatae, per germinationem multipolarem reproducentes. Pseudomycelium formatur. In agaro 'YM', post unum mensem ad $25{ }^{\circ} \mathrm{C}$, cultura butyrosa vel rugosus, cremea, umbonatus vel pulvinatus, margine fimbriata cum mycelio. In agaro farinae Zea mays post die 7 ad $25{ }^{\circ} \mathrm{C}$ pseudohyphae formantur. Ascosporae non formantur.

Glucosum (exiguum) fermentur at non galactosum, sucrosum, maltosum, lactosum, raffinosum, trehalosum, cellobiosum nec D-xylosum. Glucosum, sucrosum, raffinosum (exiguum vel nullum), trehalosum, maltosum, melezitosum, $\alpha$-methyl D-glucosidum, amylum solubile, cellobiosum, salicinum, D-xylosum, L-arabinosum, D-ribosum, methanolum (fortasse tardum), ethanolum, glycerolum, ribitolum, 


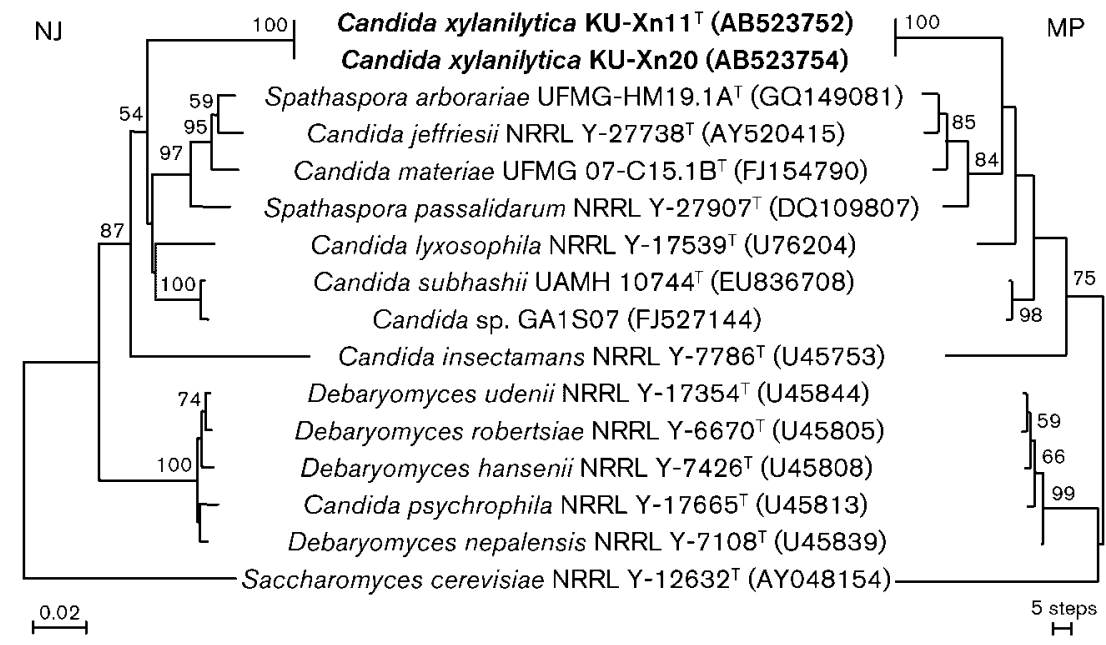

Fig. 1. Phylogenetic tree based on sequences of the D1/D2 domain of the LSU rRNA gene, showing the positions of the two strains of Candida xylanilytica sp. nov., with respect to closely related species. The neighbour-joining (NJ) phylogenetic tree was reconstructed from evolutionary distance data corrected by the two-parameter transformation of Kimura (1980). The maximum-parsimony (MP) phylogenetic tree was reconstructed using the maxmini branch-and-bound algorithm (Nei \& Kumar, 2000). Numbers indicate percentages of bootstrap sampling, derived from 1000 samples. Bars, 0.02 substitutions per nucleotide position (NJ) or 5 steps (MP).
D-mannitolum, D-glucitolum, acidum DL-lacticum, acidum succinicum (lente vel nullum), acidum D-gluconicum (lente vel nullum), D-glucosaminum, $\mathrm{N}$-acetyl-D-glucosaminum, 2ketogluconicum, propanum-1,2-diolum (lente), xylanum et arbutinum assimilantur at non inulinum, melibiosum, galactosum, lactosum, L-sorbosum, L-rhamnosum, D-arabinosum, erythritolum, galactitolum, inositolum, acidum citricum, hexadecanum, xylitolum, 5-ketogluconicum, acidum D-glucuronicum, arabinitolum, D-glucono-1,5-lactonum, acidum D-galacturonicum nec butanum-2,3-diolum. Ethylaminum, L-lysinum et cadaverinum assimilantur at non nitricum nec nitrocum. Crescit sine vitaminis (exiguum). Crescit in $50 \%$ glucosum et $60 \%$ glucosum (exiguum). Non crescit in $0.01 \%$ cycloheximido, $0.1 \%$ cycloheximido nec $10 \%$ natrii chloridum $/ 5 \%$ glucosum. Amylum non formatur. Diazonium caeruleum B non respondens. Ureum non hydrolysatur. Maxima temperatura crescentiae: $42{ }^{\circ} \mathrm{C}$. Proportio molaris guanini + cytosini in acido deoxyribonucleico: $38.3,39.2 \mathrm{~mol} \%$ (per HPLC). Ubiquinonum majus: Q-9. Typus strips KU-Xn11 $1^{\mathrm{T}}\left(=\mathrm{NBRC} 106499^{\mathrm{T}}=\mathrm{BCC}\right.$ $34694^{\mathrm{T}}=\mathrm{CBS} 11761^{\mathrm{T}}$ ) isolatus ex putrefacio Zea mays axis, Nakhon Ratchasima Provincia, Thailandia, conservatur in
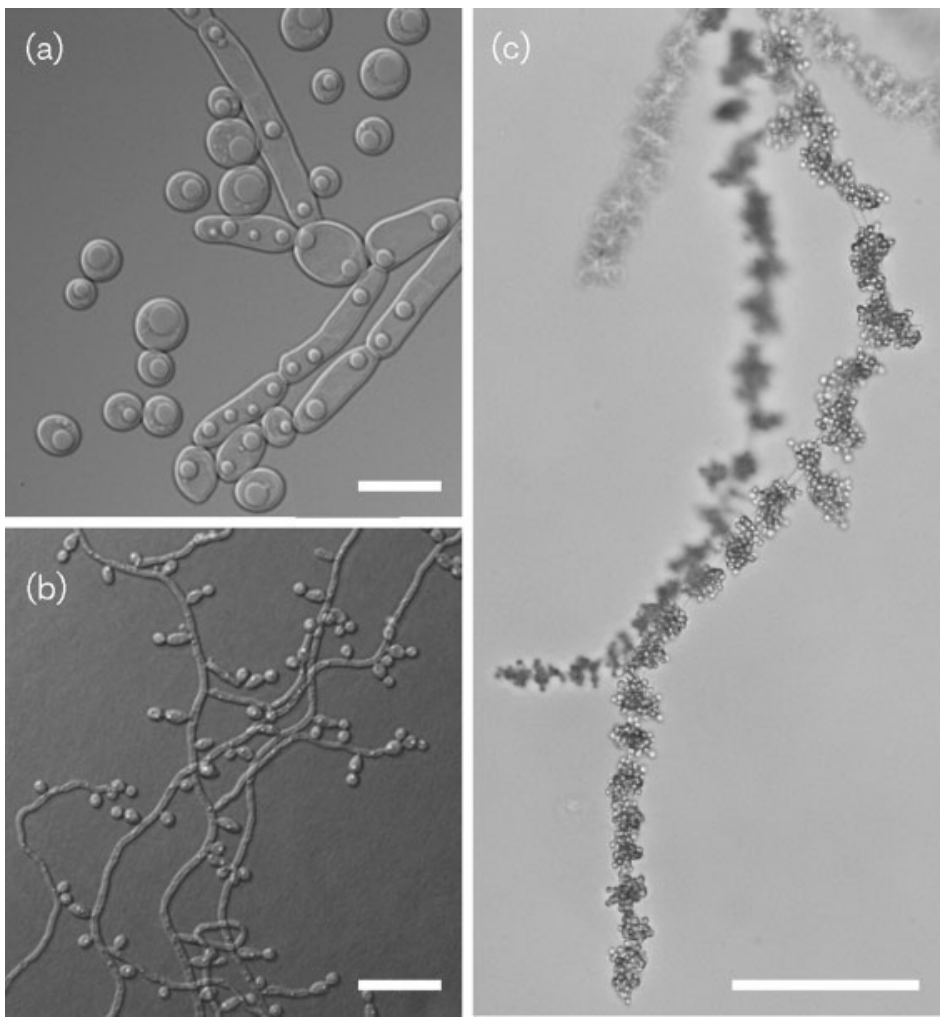

Fig. 2. Morphology of vegetative cells of strain $\mathrm{KU}-\mathrm{Xn} 11^{\top}$. (a) Vegetative cell grown in $\mathrm{YM}$ broth for 3 days at $25^{\circ} \mathrm{C}$. (b) Pseudomycelia produced on slide culture with cornmeal agar after 7 days at $25{ }^{\circ} \mathrm{C}$. (c) Pseudomycelia produced on Dalmau plate culture with cornmeal agar after 14 days at $25^{\circ} \mathrm{C}$. Bars, $10 \mu \mathrm{m}$. 
collectione culturarum in 'NITE Biological Resource Center (NBRC)', Kisarazu, Chiba, Japania ut NBRC $106499^{\mathrm{T}}$, et collectione culturarum in 'BIOTEC Culture Collection (BCC), National Center for Genetic Engineering and Biotechnology (BIOTEC)', Pathumthani, Thailandia ut BCC $34694^{\mathrm{T}}$, et 'Centraalbureau voor Schimmelcultures (CBS)', Utrecht, the Netherlands ut CBS $11761^{\mathrm{T}}$ deposita est.

\section{Description of Candida xylanilytica Boonmak, Limtong, Jindamorakot, Am-In, Yongmanitchai, Suzuki, Nakase \& Kawasaki sp. nov.}

Candida xylanilytica (xy.lan.i.ly'ti.ca. N.L. n. xylanum xylan, a plant polysaccharide; Gr. adj. lutikos - $\hat{e}$-on able to loose, able to dissolve; N.L. fem. adj. xylanilytica hydrolysing xylan).

After growth in YM broth for 3 days at $25{ }^{\circ} \mathrm{C}$, loose floating islets and heavy sediment are present. Cells proliferate by multilateral budding and are spheroidal, ovoidal, ellipsoidal or elongate, $3.2-9.5 \times 3.2-23.2 \mu \mathrm{m}$ and occur singly, in pairs or in small clusters. Pseudomycelia are produced. After growth in YM agar for 1 month at $25{ }^{\circ} \mathrm{C}$, streak culture is smooth, butyrous, cream-coloured and umbonate with ciliate margin. Sometimes pulvinate wrinkled colonies are obtained from smooth colonies. In Dalmau plate culture on cornmeal agar after 5 days at $25{ }^{\circ} \mathrm{C}$, pseudomycelia are produced abundantly. Blastoconidia are formed in clusters. Ascospores are not produced from individual strains or mixed culture on $5 \%$ malt extract agar, cornmeal agar, Fowell's acetate agar, diluted vegetable juice agar or YM agar after 5 weeks at $15{ }^{\circ} \mathrm{C}$. Fermentation of glucose is positive but fermentation of galactose, sucrose, maltose, lactose, raffinose, trehalose, cellobiose and xylose is negative. Glucose, sucrose, raffinose (weakly positive or negative), trehalose, maltose, melezitose, $\alpha$-methyl D-glucoside, soluble starch, cellobiose, salicin, D-xylose, L-arabinose, D-ribose, methanol (slow), ethanol, glycerol, ribitol, D-mannitol, D-glucitol, DL-lactic acid, succinic acid (latent or negative), D-gluconic acid (latent or negative), D-glucosamine, $\mathrm{N}$-acetyl-D-glucosamine, 2-ketogluconic acid, propane-1,2-diol (latent), xylan, ethylamine, L-lysine and cadaverine are assimilated, but inulin, melibiose, galactose, lactose, L-sorbose, L-rhamnose, D-arabinose, erythritol, galactitol, inositol, citric acid, hexadecane, xylitol, 5-ketogluconic acid, D-glucuronic acid, arabinitol, D-glucono-1,5-lactone, D-galacturonic acid, butane-2,3-diol, nitrate and nitrite are not assimilated. Growth in vitamin-free medium is weak. Growth at $42{ }^{\circ} \mathrm{C}$ but not at $45{ }^{\circ} \mathrm{C}$. Growth on medium containing $0.01 \%$ cycloheximide and medium containing $10 \% \mathrm{NaCl}$ and $5 \%$ glucose is negative. Growth on medium with $50 \%$ glucose is positive but weakly positive with $60 \%$ glucose. Starch formation and gelatin liquefaction are negative. Tween 80 hydrolysis is positive. Diazonium blue $\mathrm{B}$ and urease reactions are negative. DNA $\mathrm{G}+\mathrm{C}$ content is 38.3$39.2 \mathrm{~mol} \%$. Major ubiquinone is Q-9.
The type strain, KU-Xn11 $1^{\mathrm{T}}\left(=\mathrm{NBRC} 106499^{\mathrm{T}}=\mathrm{BCC}\right.$ $34694^{\mathrm{T}}=$ CBS $11761^{\mathrm{T}}$ ), was isolated from decayed corn cobs at the National Corn and Sorghum Research Center, Nakhon Ratchasima, Thailand. A living culture of the type is deposited at the NITE Biological Resources Center (NBRC), Department of Biotechnology, National Institute of Technology and Evaluation (NITE), Chiba, Japan, as NBRC $106499^{\mathrm{T}}$, the BIOTEC Culture Collection (BCC), National Center for Genetic Engineering and Biotechnology (BIOTEC), Pathumthani, Thailand, as BCC $34694^{\mathrm{T}}$, and the Centraalbureau voor Schimmelcultures, Utrecht, the Netherlands, as CBS $11761^{\mathrm{T}}$.

\section{Acknowledgements}

This work was supported in part by the Institute for Fermentation, Osaka (IFO) fund. Special thanks go to Mr Shinya Ninomiya and $\mathrm{Mr}$ Atsushi Yamasaki for kindly support and suggestion. Many thanks are due to the students of the laboratory of Professor Savitree Limtong for their assistance. This work was facilitated by the Joint Research Project between BIOTEC and NITE.

\section{References}

Adam, H., Groenewald, M., Mohan, S., Richardson, S., Bunn, U., Gibas, C. F., Poutanen, S. \& Sigler, L. (2009). Identification of a new species, Candida subhashii, as a cause of peritonitis. Med Mycol 47, 305-311.

Altschul, S. F., Madden, T. L., Schäffer, A. A., Zhang, J., Zhang, Z., Miller, W. \& Lipman, D. J. (1997). Gapped BLAST and PSI-BLAST: a new generation of protein database search programs. Nucleic Acids Res 25, 3389-3402.

Barbosa, A. C., Cadete, R. M., Gomes, F. C. O., Lachance, M. A. \& Rosa, C. A. (2009). Candida materiae sp. nov., a yeast species isolated from rotting wood in the Atlantic Rain Forest. Int J Syst Evol Microbiol 59, 2104-2106.

Beg, Q. K., Kapoor, M., Mahajan, L. \& Hoondal, G. S. (2001). Microbial xylanases and their industrial applications: a review. Appl Microbiol Biotechnol 56, 326-338.

Bhadra, B., Rao, R. S., Singh, P. K., Sarkar, P. K. \& Shivaji, S. (2008). Yeasts and yeast-like fungi associated with tree bark: diversity and identification of yeasts producing extracellular endoxylanases. Curr Microbiol 56, 489-494.

Cadete, R. M., Santos, R. O., Melo, M. A., Mouro, A., Gonçalves, D. L., Stambuk, B. U., Gomes, F. C. O., Lachance, M. A. \& Rosa, C. A. (2009). Spathaspora arborariae sp. nov., a D-xylose-fermenting yeast species isolated from rotting wood in Brazil. FEMS Yeast Res 9, 13381342.

Felsenstein, J. (1985). Confidence limits on phylogenies: an approach using the bootstrap. Evolution 39, 783-791.

Gilbert, H. J., Stålbrand, H. \& Brumer, H. (2008). How the walls come crumbling down: recent structural biochemistry of plant polysaccharide degradation. Curr Opin Plant Biol 11, 338-348.

Holm, C., Meeks-Wagner, D. W., Fangman, W. L. \& Botstein, D. (1986). A rapid, efficient method for isolating DNA from yeast. Gene 42, 169-173.

Kaneko, Y. \& Banno, I. (1991). Reexamination of Saccharomyces bayanus strains by DNA-DNA hybridization and electrophoretic karyotyping. IFO Res Commun 15, 30-41. 
Kimura, M. (1980). A simple method for estimating evolutionary rates of base substitutions through comparative studies of nucleotide sequences. J Mol Evol 16, 111-120.

Kurtzman, C. P. \& Robnett, C. J. (1998). Identification and phylogeny of ascomycetous yeasts from analysis of nuclear large subunit (26S) ribosomal DNA partial sequences. Antonie van Leeuwenhoek 73, 331-371.

Limtong, S., Imanishi, Y., Jindamorakot, S., Ninomiya, S., Yongmanitchai, W. \& Nakase, T. (2008). Torulaspora maleeae sp. nov., a novel ascomycetous yeast species from Japan and Thailand. FEMS Yeast Res 8, 337-343.

Mikata, K. \& Yamada, Y. (1999). The ubiquinone system in Hasegawaea japonica (Yukawa et Maki) Yamada et Banno: a new method for identify ubiquinone homologs from yeast cells. IFO Res Commun 19, 41-46.

Nei, M. \& Kumar, S. (2000). Molecular Evolution and Phylogenetics. New York: Oxford University Press.

Nguyen, N. H., Suh, S. O., Marshall, C. J. \& Blackwell, M. (2006). Morphological and ecological similarities: wood-boring beetles associated with novel xylose-fermenting yeasts, Spathaspora passalidarum gen. sp. nov. and Candida jeffriesii sp. nov. Mycol Res 110, $1232-1241$

Saitou, N. \& Nei, M. (1987). The neighbor-joining method: a new method for reconstructing phylogenetic trees. Mol Biol Evol 4, 406-425.
Tamaoka, M. \& Komagata, K. (1984). Determination of DNA base composition by reversed-phase high-performance liquid chromatography. FEMS Microbiol Lett 25, 125-128.

Tamura, K., Dudley, J., Nei, M. \& Kumar, S. (2007). MEGA4: molecular evolutionary genetics analysis (MEGA) software version 4.0. Mol Biol Evol 24, 1596-1599.

Thompson, J. D., Gibson, T. J., Plewniak, F., Jeanmougin, F. \& Higgins, D. G. (1997). The CLUSTAL_X windows interface: flexible strategies for multiple sequence alignment aided by quality analysis tools. Nucleic Acids Res 25, 4876-4882.

van der Walt, J. P., Scott, D. B. \& van der Klift, W. C. (1972). Six new Candida species from South Africa insect sources. Mycopathologia 47, 221-236.

van der Walt, J. P., Ferreira, N. P. \& Steyn, R. L. (1987). Candida lyxosophila sp. nov., a new D-xylose fermenting yeast from southern Africa. Antonie van Leeuwenhoek 53, 93-97.

Yarrow, D. (1998). Methods for the isolation, maintenance and identification of yeasts. In The Yeasts, a Taxonomic Study, 4th edn, pp. 77-100. Edited by C. P. Kurtzman \& J. W. Fell. Amsterdam: Elsevier. doi: 10.1016/B978-044481312-1/50014-9.

Zhang, Y. H. P., Himmel, M. E. \& Mielenz, J. R. (2006). Outlook for cellulase improvement: screening and selection strategies. Biotechnol Adv 24, 452-481. 